\title{
Digitalization as a Key Factor of Increasing Investment Attractiveness and Innovative Development of Industrial Enterprises
}

\author{
O.A. Bulavko ${ }^{1}$, B.Ya. Tatarskih ${ }^{1}$, L.R. Tuktatova ${ }^{1, *}$ and I.A. Naugolnova ${ }^{1}$ \\ *Corresponding author, E-mail: vikigor163@ mail.ru \\ ${ }^{1}$ Samara State University of Economics, Samara, Russia
}

\begin{abstract}
The relevance of the study is stipulated by the need to increase the in-vestment attractiveness of the real sector of the economy in the context of global changes associated with the new industrial revolution "Industry 4.0". In this regard, the article is aimed at identifying indicators that determine the innovative potential of industrial complex enterprises, identifying factors and criteria for the effective development of industrial enterprises based on the introduction of innovative and digital technologies and increasing the investment attractiveness of high-tech industries. The leading approach to the study of this problem is a systematic and comprehensive analysis of the reasons of technological lag of industrial enterprises and the factors restraining their effective development. As a result, the possibilities of the economy growth at the account of the tools of the industrial investment policy were proved. The materials of the article are of practical value for researchers and specialists involved in the problems of increasing the investment attractiveness and economic efficiency of industrial enterprises in conditions of economy digitalization. The materials of the article are of practical value for researchers and specialists involved in the problems of increasing the investment attractiveness and economic efficiency of industrial enterprises in conditions of digitalization of the economy.
\end{abstract}

Keywords: digitalization, investment attractiveness, industrial and investment policy tools, cluster policy, industrial policy, Industry 4:0.

\section{Introduction}

The problem of applying digital technologies at industrial enterprises is an important area of research. The modern period is characterized by the process of transition to the development of high-tech branches of production and the formation of a new information society. This increases the need for the development and implementation of software, the release of new specialized equipment. In accordance with the new requirements, industrial enterprises should reorient their work to high-tech products, increasing the volume of investments in scientific research and increasing indicators of investment attractiveness. In order to achieve this goal, the following tasks were being solved:

- to prove the need in the tools of stimulating economic growth, contributing to the development of industrial enterprises and high-tech industries;

- to identify the main factors and reasons of the low level of cluster development;

- to determine criteria and indicators of investment attractiveness within the frame of improving the effective development of the industrial cluster as the basis for the transformation of the digital economy.

\section{Problem Statement}

At the end of $2017,55 \%$ of domestic enterprises spent on digitalization of production and management processes and development of IT infrastructure not more than $1 \%$ of companies' budgets. Only in $6 \%$ of cases this figure was about $5 \%$. In foreign companies the cost of digitalization also rarely exceeds this threshold [1].

\section{Research Questions}

There is no sharp and large-scale technological breakthrough in the world industry at present but no one denies the prospects for high efficiency and global changes associated with the new industrial revolution "Industry 4.0". It is based on the principles of digitalization of vertical processes within an enterprise and horizontal links between manufacturers, customers, intermediaries, partners and other counteragents [2]. 


\section{Purpose of the Study}

While carrying out the research and substantiation of the directions of development of investment attractiveness of the industry and the need of the use of high technologies in the industrial sector the authors were oriented towards the global development trends of the digital economy, key tasks of the Federal Laws "On Industrial Policy in the Russian Federation" [3], programs of the Government of the Russian Federation "Digital Economy of the Russian Federation" [4], "The Development of Industry and Increasing of its Competitiveness" [5].

\section{Research Methods}

In the process of the research, the method of systemic and complex analysis was used, which made it possible to study the constraints of the effective development of industrial enterprises and the reasons of their technological lag as well as determined the indicators determining the innovative potential of industrial complex enterprises. The methodical and practical base of the research is the practical activity of the largest industrial enterprises. The empirical base of the study was the state statistics on the dynamics of investment processes and the development of cluster policy as well as the development of industrial production in Russia. The main tools for stimulating economic growth, contributing to the development of enterprises and allowing the shifting of the vector of resource provision towards high-tech industries, are, in our opinion, new technologies, such as digitalization and new industrial policy development tools. According to the World Bank report [6], information technologies cover all areas of human activities and state activities and are becoming increasingly important in the development of the economy, increasing of the national welfare and receiving of the so-called "digital dividends". The report defines digital economy as a paradigm of accelerating economic development with the help of digital technologies $[6,7]$. That means that digital economy is a powerful tool and an obligatory condition for the effective development of the economy of any country. S.S. Tatarinova devides all the existing approaches to the understanding of the collocation "digital dividends" into two groups [8]. According to the "classical" approach, "digital economy" is an economy based on digital technologies and at the same time it is more correct to characterize exclusively the field of electronic goods and services. According to the "advanced" approach "digital economy" is the economic production and the use of digital technologies. The concept of digital economy got its start in the 1990s; its advantages were formulated by N. Negroponte, the founder of the laboratory of Massachusetts Technological Institute [7]. In 1995 he spoke about the disadvantages of classic goods (weight, raw materials, transport) and the advantages of the new economy (lack of weight of goods, virtuality, almost unnecessary raw materials and instantaneous global movement of goods). Later in 1999 B. Gates also noted the significant impact of digitalization of the economy on the development of industry and economy of each country. According to him, in future, two types of companies will stay on the market: online companies and companies that "went out of business" [2].

\section{Findings}

Modern trends confirm the correctness of his ideas. Moreover, countries that do not pay due attention to the processes of "digitalization" and do not invest in the development of innovative technologies will not be able to compete on the world market in the near future.

The wide use of high technologies in the industrial sphere shows the need for the development of scientific and technological research projects based on certain knowledge, which are prerequisites for long-term economic growth and welfare.

At the same time, synergistic effect can be obtained due to the breakthrough of the fourth industrial revolution, defined as "Industry 4.0", the basis of which is the "digitalization" of industry and production. P.V. Schulze [9] proves in his research that "the integration of high technologies and traditional industry into a network of active players, grouped around an "authorized" state, characterizes the European model. This model is based on the elements of reindustrialization and a sufficient reserve for additive technologies, digital design and modeling. A technological breakthrough in many industries is possible provided that new developments are implemented and scientific research is funded. When creating the elements of the new economic policy, there is a strong correlation between the pace of economic development and the share of investments in human and fixed capital in the GDP. The combination of these factors gives about $85 \%$ of economic growth.

According to G. Reischauer [10] "Industry 4.0" is the direction of the innovation course in industry which combines the institutionalization of the innovation system, business, science and politics". This clarification of identity adds to the understanding of the relationship between production and politics and the need for technological changes in production.

Some authors think that a very important argument is that "Centralized functions, such as research and development, asset optimization, corporate planning (strategies, investment planning) are of great value for business" [11]. Effective development of enterprises is impossible without new tools of industrial policy regulation. Now there is a significant number of well-known relevant definitions of this concept, and the industrial policy itself (though it is rather the level of government regulation) ranges from rigid (comprehensive state planning and directive centralized management) to soft involving only the creation of institutional conditions for the development of private business. In our opinion, industrial 
policy is, first of all, the coordination of strategies of private business, state and society, where government sets certain priorities for the development of industry and its location and then makes adjustments depending on the needs of society and business [12]. The following indicators can be called the driving force that determines the innovative potential of industry:

Table 1. Indicators Determining the Innovative Potential of Industrial Complex Enterprises

\begin{tabular}{|c|c|}
\hline Indicators & Description \\
\hline \multicolumn{2}{|r|}{ Subjective } \\
\hline 1 Scientific Potential & $\begin{array}{l}\text { Highly qualified potential capable of translating and generating } \\
\text { innovations }\end{array}$ \\
\hline 2 Economic Situation & $\begin{array}{l}\text { High degree of the development of market relations, financial } \\
\text { market, investment market and investment-innovation services }\end{array}$ \\
\hline $\begin{array}{l}3 \text { Legislative and } \\
\text { Normative Base }\end{array}$ & $\begin{array}{l}\text { Stable legal regime; independent judicial system; tax benefits } \\
\text { securing }\end{array}$ \\
\hline 4 Risk Factors & $\begin{array}{l}\text { State guarantees to protect Russian and foreign investors from } \\
\text { non-commercial risks; low investment risks }\end{array}$ \\
\hline 5 Labour Resources & Low proportion of the population of retirement age \\
\hline $\begin{array}{l}\text { 6 Infrastructure } \\
\text { Development of the } \\
\text { Region }\end{array}$ & $\begin{array}{l}\text { The presence of large Russian and foreign consulting } \\
\text { organizations and institutional investors. Focus on business } \\
\text { motivation, support from state and regional institutions. High level } \\
\text { of digitalization and information support of industrial enterprises }\end{array}$ \\
\hline
\end{tabular}

Source: compiled by the authors.

The clustering process contributes to the efficiency of industrial enterprises. The growth of investment and innovation activity of enterprises, the development of scientific and educational potential is the result of the effective implementation of cluster policy.

Cluster policy is the element of economic and industrial policy of the state, aimed at the effective development of economic sectors, attracting investment resources and balanced growth of socio-economic indicators.

At the present moment, for various reasons, there is no balance between socio-economic indicators which leads to problems in the development of economic clusters. In our opinion there may be the following factors hindering the effective development of industrial clusters and reasons for their technological lag:

Table 2. Factors and Reasons

\begin{tabular}{|c|c|}
\hline Key factors & Main Reasons \\
\hline $\begin{array}{l}\text { 1. Focus on raw materials } \\
\text { 2. Low level of innovative activities in the } \\
\text { country and economy } \\
\text { 3. High degree of deterioration of } \\
\text { production equipment at industrial enterprises. } \\
\text { Low level of automation and production } \\
\text { mechanization } \\
\text { 4. Insufficient state support of the real } \\
\text { sector of the economy. Absence or inefficiency } \\
\text { of cluster policy. High taxes not allowing new } \\
\text { young companies to increase capital } \\
5 \text {. Low level of competition in the market, } \\
\text { high proportion of monopolization of the } \\
\text { economy } 6 \text {. Lack of motivation and interest for } \\
\text { company management and staff in increasing } \\
\text { productivity of labor } \\
\text { 7. Low level of digitization of processes at } \\
\text { industrial enterprises }\end{array}$ & $\begin{array}{l}\text { 1. Mistakes in strategic planning } \\
\text { 2. Lack or low level of investments in a } \\
\text { particular sector } \\
\text { 3. The insufficient level of the added } \\
\text { value, which does not allow investing in the } \\
\text { renewal of equipment. Expensive credits. } \\
\text { Outdated technologies } \\
\text { 4. The budget deficit, bad distribution of } \\
\text { income of state and semi-state companies. } \\
\text { Lack of development of the public-private } \\
\text { partnership (hereinafter PPP) } \\
\text { 5. High entry barriers for new players } \\
\text { 6. Mentality, level of education, bad } \\
\text { system of motivation and stimulation of } \\
\text { labor, low level of added value } \\
\text { 7. Lack of funding. Staff Resistance. } \\
\text { Lack of experience }\end{array}$ \\
\hline
\end{tabular}

Source: compiled by the authors.

When forming and developing cluster investment attractiveness plays a decisive role, as it is a system of indicators that enables an investor to get the desired level of income with a minimum level of risk and a sufficient level of financial reliability.

The assessment of investment risk, which may arise in a situation of uncertainty and lead to possible financial losses, also plays an important role. Some authors say that "the company's investment potential and investment risk are expressed by one common indicator that allows you to apply rating scores" [13]. Rating assessments are necessary in determining the criteria proposed by the authors of this study (Table 3 ). 
Table 3. Criteria Determining the Effective Development of Clusters

\begin{tabular}{|l|c|}
\hline Investment attractiveness of a cluster & $\begin{array}{c}\text { Necessary conditions } \\
\text { for the emergence and development of } \\
\text { clusters }\end{array}$ \\
\hline investment potential & presence of a leading enterprise \\
\hline forecasted performance level & human resources \\
\hline level of investment risks & socio-economic conditions \\
\hline $\begin{array}{l}\text { level of digitalization and informatization of } \\
\text { enterprises }\end{array}$ & availability of market \\
\hline
\end{tabular}

Source: compiled by the authors.

The problems of innovative development of enterprises have been viewed for a very long time. But they become especially actual and vital with the transition to digital economy. This transition is also a powerful push to its realization.

The term "information economy" was introduced by M. Porat [12] in 1976 but it has been used widely in scientific publications only from 1998 after the monography of M. Castells was published [14].

"Information Age: Economy, Society, Culture". Although the role of information in economy began to be actively studied in the middle of the 20th century, with the development of computer technology and information theory, the theory of digital economy continues to develop and IT technologies have become the most important resources of society, the world economy and business.

\section{Conclusion}

The number of publications on digitalization has increased substantially in the last decade. A.B. Anisiforov [13] and M.G. Dzhanelidze [15] note the key role of informatization in business development, the growth of its innovative potential and the increase of the efficiency of its activities.

The authors of this article agree with the scientists, in addition they emphasize the importance of digitalization in increasing the investment attractiveness of the real sector of the economy in the context of global changes associated with the new industrial revolution "Industry 4.0" [16].

Digitalization is viewed as one of the indicators determining the innovative potential of enterprises of the industrial complex; as a factor constraining the effective development of the domestic industry; as one of the reasons of low investment attractiveness; as a criterion determining the effective development of clusters.

Thus, according to the authors of the article, digitalization is defined as an integral component of all business processes. The transition to the innovation scenario opens the way to modernize the digital economy, to increase the pace and efficiency of its development on the base of the intensive use of domestic intellectual potential and the development of advanced technologies.

\section{References}

1. Russian industry 4.0: How not to be late for the train to the future. The analytical statement - survey: IT in Industry CNEWS. Retrieved from: http://www.cnews.ru/reviews/it_v_promyshlennosti_2018/articles/rossijskaya_promyshlennost_40_kak_ne_opozdat_ na_poezd_v_budushchee. Accessed: 02.10.2018. [in Rus.] (2018).

2. B. Gates, Information flow is your lifeblood. In A. Hopkins \& J. Potter (Eds.), Business @ the Speed of Thought: Succeeding in the Digital Economy Hardcover (pp. 1-63). Harlow: Pearson Education Limited (1999).

3. Federal Law "On Industrial Policy in the Russian Federation" from 31.12.2014 N 488-FZ (the last edition). Retrieved from: http://www.consultant.ru/document/cons_doc_LAW_173119/. Accessed: 02.10.2018. [in Rus.] (2014).

4. Program "Digital Economy of the Russian Federation". Retrieved from: http://www.consultant.ru/document/cons_doc_LAW_221756/2369d7266adb33244e178738f67f181600cac9f2/ Accessed: 02.10.2018. [in Rus.] (2017).

5. RF Government Decree from 15.04.2014 N 328 (Edition from 10.02.2018) "On Approval of the State Program of the Russian Federation". The Development of the Industry and the Increasing of its Competitiveness. Retrieved from: http://www.consultant.ru/document/cons_doc_LAW_162176/. Accessed: 02.10.2018. [in Rus.] (2014).

6. Digital dividends. World development Report 2016 Overview World Bank. Retrieved from: https://openknowledge.worldbank.org/bitstream/handle/10986/23347/210671RuSum.pdf. Accessed: 09.10.2018. [in Rus.] (2016).

7. N. Negroponte, Selected excerpts. In A.A. Knopf (Ed.), Being digital (pp. 1-5). New York: University of Chicago Press (1996).

8. S.S. Tatarinova, Digital economy and law: new challenges - new perspectives. Juridical Vestnik of Samara University, 3(3), 62-66 [in Rus.] (2017). 
9. P.W. Schulze, Future of industry: The fourth revolution - functions of state and society. Economic Revival of Russia, 2(52), 39-46 (2017).

10. G. Reischauer, Industry 4.0 as policy-driven discourse to institutionalize innovation systems in manufacturing. Technological Forecasting and Social Change, 132, 26-33. DOI: 10.1016/j.techfore.2018.02.012 (2018).

11. O.A. Bulavko, Industrial and investment policy in the post-crisis modernization of Russian industry. Thesis of the Doctor of Economic Sciences. Saint-Petersburg: St. Petersburg State University of Economics and Finance. [in Rus.] (2013).

12. M. Porat, The information economy. Washington: U.S. Government Printing Office (1977).

13. A.B. Anisiforov, Key tasks of information management at an enterprise in the digital economy. In V.E. Tschepinin \& S.V. Schirokova (Eds.), Fundamental and Applied Research in the Field of Management, Economics and Trade. Collection of Works of Scientific Practical and Educational Conference (pp. 88-93), in 3 parts, St. Petersburg: Peter the Great St. Petersburg Polytechnic University, [Institute of industrial management, economics and trade] [in Rus.] (2018).

14. M. Castells, The Rise of the Network Society. The Information Age: Economy, Society and Culture Vol. I (second edition). Oxford, UK: Blackwell (2009).

15. M.G. Dzhanelidze, Digitalization as a factor of innovative development. In S.V. Kuznetsov (Ed.), Problems of Transformation and Regulation of Regional Socio-Economic Systems: Collection of Scientific Works, (pp. 72-75). St. Petersburg, St. Petersburg State University of Aerospace Instrumentation) [in Rus.] (2018).

16. A. Telukdarie, E. Buhulaiga, S. Bag, S. Gupta, \& Z. Luo, Industry 4.0 implementation for multinationals. Process Safety and Environmental Protection, 118, 316-329. DOI: 10.1016/j.psep.2018.06.030. URL: http://www.sciencedirect.com/science/article/pii/S0957582018303719 (2018). 